\title{
The Impact of COVID-19 Lockdowns on Sustainable Indexes
}

\author{
Helen Chiappini ${ }^{1, *(\mathbb{D})}$, Gianfranco Vento ${ }^{2,3}$ and Leonardo De Palma 4 \\ 1 Department of Management and Business Administration, G. d'Annunzio University of Chieti-Pescara, \\ 65127 Pescara, Italy \\ 2 Faculty of Business \& Management, Regent's University London, London NW14NS, UK; \\ g.vento@unimarconi.it \\ 3 Department of Economic and Business Sciences, Guglielmo Marconi University, 00193 Rome, Italy \\ 4 Independent Researcher, 66100 Chieti, Italy; leonardodepalma@ymail.com \\ * Correspondence: helen.chiappini@unich.it
}

check for

updates

Citation: Chiappini, H.; Vento, G.; De Palma, L. The Impact of COVID-19 Lockdowns on Sustainable Indexes. Sustainability 2021, 13, 1846. https://doi.org/10.3390/ su13041846

Academic Editor: Olaf Weber

Received: 8 January 2021

Accepted: 5 February 2021

Published: 8 February 2021

Publisher's Note: MDPI stays neutral with regard to jurisdictional claims in published maps and institutional affiliations.

\begin{abstract}
This paper analyzes the response of sustainable indexes to the pandemic lockdown orders in Europe and the USA, contributing to both the research on the effects of the global pandemic outbreak and the resiliency of sustainable investments under market distress. Our results demonstrate that sustainable indexes were negatively impacted by lockdown orders; however, they did not show statistically significant different abnormal returns compared to traditional indexes. Similarly, our empirical results confirm that sustainable screening strategies (negative, positive, best in class) did not have an influence during such announcements. These results are robust across several model specifications and robustness tests, including nonparametric tests, generalized autoregressive conditionally heteroskedastic (GARCH) estimation of abnormal returns, and alternative events. The findings suggest that investors do not have to pay the price for the investments in sustainable assets when a bear market occurs; consequently, ceteris paribus, these investments appear suitable for financial-first investors. Such results have relevant practical consequences in terms of sustainable investment attractiveness and market growth.
\end{abstract}

Keywords: sustainable indexes; financial markets; COVID-19; event study

\section{Introduction}

Sustainable investments and all related concepts under this umbrella-term-such as ethical, responsible, environmental social and governance (ESG) investments [1,2]-have gained an exceptional interest [3-5] and growth of assets under management [6] over the last years. Although a common definition of sustainable investments does not exist, they are broadly defined as those seeking to address or reduce some social or environmental issues while pursuing a financial return [1,2].

Investors are increasingly demanding assets that play a relevant role in alleviating the social and environmental challenges of our times, such as poverty, malnutrition, financial exclusion and climate change. In response, the financial industry has developed investment strategies based on extra-financial criteria (e.g., the ESG criteria) [7], resulting in both more or less proactive classes of sustainable investments [8-10] and in several different financial products [5].

On the other side, a wide range of scholars are investigating the theme of sustainable investments, trying to shed light on different research questions (e.g., [11,12]), among which "does it pay to be good?" [11].

Despite the increased interest and growth of the sustainable market, the so-called financial-first investors [13] - investors looking for financial return while contributing to sustainability issues - remain cautious regarding the link between financial and nonfinancial performance and worry about the risk of green (and social) washing that sustainable investments may face [14-17]. The literature provides opposing results through 
empirical investigations of the relationship between financial and non-financial performance (e.g., [11,12,18], and market downturns (e.g., [3]). While the pandemic caused by the Coronavirus Disease (COVID-19) is pushing research on sustainable investments and bear market conditions, the results are currently limited to specific areas (e.g., the Chinese stock market as in Broadstock et al. [19]) or specific sustainable ratings (e.g., the eco-fund rating used by Folger-Laronde et al. [20]).

This paper contributes to this discussion by focusing on sustainable indexes and on a relevant, although rare, event: the pandemic lockdown orders. The COVID-19 lockdowns represent unprecedented " policy interventions [..] more aggressive, broader in scope, more widespread geographically, and lengthier" than others adopted during the previous pandemics, such as the Spanish flu [21] (p. 753). In fact, the governmental policies adopted to combat the COVID-19 pandemic have led to a massive remodulation of our lives with enormous direct and indirect economic costs [21-24].

Using the event study method, our paper aims to test whether the reputational advantages [25-28] of sustainable indexes immunize them against the effects of COVID-19 lockdown announcements. Our results show that the European and the US lockdown announcements negatively impacted sustainable indexes; however, no statistically significant differences were found between the resilience of the sustainable indexes and their conventional peers during the COVID-19 outbreak. Furthermore, sustainable screening strategies did not matter during the lockdown announcements. These results are robust across several model specifications and robustness tests, including nonparametric tests, GARCH estimation of abnormal returns, and alternative events.

In addition to contributing to the recent literature on the COVID-19 market reactions (e.g., [29-33]), our findings contribute to the ongoing debate over the performance of sustainable investments in the following ways. First, our study makes it possible to evaluate the financial performance of sustainable investments in times of exceptional crisis from a worldwide health emergency and by uncommon measures put in place by governments to preserve global health.

Second, despite the plethora of studies investigating the relationship between sustainable performance and financial performance [12,18], relatively few studies have analyzed indexes $[34,35]$. To the best of our knowledge, there are few investigations of sustainable indexes over crisis periods [27,36], while only a few studies focus on sustainable funds (e.g., [3,37-39]) during market downturns. This may be due to the fact that most indexes were established after the most severe market crises (e.g., the dot-com crisis, the global financial crisis, and the European sovereign debt crisis). Therefore, our study is particularly timely given the number of sustainable indexes launched in the last years $[40,41]$ and the lack of studies addressing them [34,35].

Third, our analysis is relevant because indexes represent the performance of respective market portfolios and allow investors to evaluate the performance of sustainable investments without considering management costs [34,42] related to other types of investments (e.g., investment funds). Moreover, an empirical investigation of market indexes is relevant given the number of products (e.g., structured products, exchange-traded funds (ETFs), exchange-traded notes (ETNs), and funds) that adopt a passive management strategy for the purpose of replicating market indexes [43,44].

Finally, focusing on several sustainable indexes allows us to consider different types of sustainable scores, instead of just one score as in previous research on indexes and market shocks (e.g., $[27,36])$ or by recent research on sustainable investments and the COVID-19 pandemic (e.g., $[19,20])$.

The remainder of this paper is organized as follows: Section 2 provides an overview of the literature on sustainable investments, financial crises, and investment strategies identifying the hypotheses of our research. Section 3 presents methods and data, while Section 4 presents and discusses the main findings. Finally, Section 5 concludes. 


\section{Literature Review and Hypotheses Development}

There is a well-established area of research focused on sustainable portfolio performance, questioning "does it pay to be good?" [45]. The theory has identified the sustainable investment opponents, supporters, and those who are indifferent [4]. The opponents generally argue that sustainable investments reduce the investment opportunities (e.g., [7]) and increase costs due to the screening process (e.g., [46,47]) with an obvious negative impact on risk and return. Supporters, on the contrary, argue that sustainable investments may benefit from firms' "good reputation and sustainable competitive advantage" [27] even during market shocks [48]. More specifically, good sustainable performance may produce moral capital or goodwill among firm stakeholders $[25,26]$, that, in turn, provides "insurance-like protection" preserving financial performance $[25,26]$ also when firms "are adversely affected in the event of a crisis" ([28] p. 645). Lastly, those who are indifferent claim that sustainable investments are neutral in terms of risk-return because sustainability is not valued from a financial perspective (e.g., [49,50]).

On the empirical side, studies have investigated the performance of sustainable funds, with only a few focusing on sustainable indexes [34], perhaps due to the recent development of this market [35,40,41]. The study by Cunha et al. [35] provides an overview of sustainable indexes and their market benchmarks, showing the neutral, positive, or mixed performance (Table 1). A critical review of studies analyzed by Cunha et al. [35], however, does bring to light that most studies focus on one index and its market peer (e.g., [34,51,52]), while only a few analyzed a set of indexes [42,53-55]. Moreover, previous analyses appear highly concentrated around two sustainable indexes: the DJSI and the FTSE4Good (Table 1).

Table 1. Sustainable indexes and market benchmarks: an overview.

\begin{tabular}{|c|c|c|}
\hline Neutral & Positive & Mixed \\
\hline $\begin{array}{l}\text { Sauer (1997) } \\
\text { Managi, Okimoto and Matsuda (2012)*,a,b } \\
\text { Ortas, Burritt and Moneva (2013) b } \\
\text { Ur Rehman et al. (2016) *,b } \\
\text { Lean and Pizzutilo (2020) }\end{array}$ & $\begin{array}{l}\text { Statman (2000) } \\
\text { Consolandi et al. (2008) } \\
\text { Collison et al. (2008) } \\
\text { Ortas et al. (2013) }^{\mathrm{a}} \\
\text { Ang (2015) }\end{array}$ & $\begin{array}{l}\text { Schröder (2007) *,a,b } \\
\text { Hoti, McAleer and Pauwels (2007) }{ }^{*, a} \\
\text { Ortas, Moneva and Salvador (2012) } \\
\text { Cunha and Samanez (2013) } \\
\text { Belghitar, Clark and Deshmukh (2014) } \\
\text { Lean and Nguyen (2014) } \\
\text { Cunha et al. (2019) }\end{array}$ \\
\hline
\end{tabular}

Source: adapted from Cunha et al. [35]. Note: the "*" identifies studies that focus on a set of ESG indexes; "a " and "b" identify studies based on the FSTE4Good index and DJSI, respectively.

Similarly, empirical studies addressing the performance of sustainable investments over market downturns are scarce, focus on sustainable funds, and are even more inconclusive $[27,37]$. In fact, to the best of our knowledge, only a few studies focus on sustainable indexes and the global financial crisis. In particular, Wu et al. [27] investigate the performance of the UK FSTE4Good, while Lean and Pizzutilo [36] analyze the MSCI SRI index over different markets (North America, Europe, Asia Pacific, Japan). Results support the outperformance of the UK FSTE4Good [27], in contrast to the findings of Lean and Pizzutilo [36], who detect that the performance of sustainable indexes does not significantly differ from their family peers, even over the global financial crisis.

Other studies have investigated the portfolio performance of sustainable funds with contradictory results. Studies documenting the outperformance of sustainable funds include Nofsinger and Varma [3], who analyzed 240 US mutual funds over the years 2000-2011, identifying two crisis periods: March 2000-October 2002 and October 2007-March 2009. The results of the alpha from CAPM, three-factor model [56], and Carhart [57] four-factor model show the outperformance of sustainable funds during crisis times. Similarly, Becchetti et al. [58] used a five-factor model including market benchmark, Fama and French [56] factors, Carhart [57] momentum factor, and the Bollen and Busse [59] timing factor, to analyze the performance of sustainable funds in several geographical areas, over the years 1992-2012. During the global financial crisis, the full sample of sustainable funds shows 
an outperformance of $0.18 \%$, while sustainable funds in Europe and Asia outperform conventional funds by $0.26 \%$ and $0.52 \%$, respectively, statistically significant at the $1 \%$ confidence level. By contrast, North-American sustainable funds show a non-statistically significant underperformance. Nakai et al. [38] used the event study method to analyze the performance of Japanese sustainable funds during the Lehman Brothers bankruptcy showing a slightly positive and statistically significant difference between sustainable and non-sustainable funds. However, the authors note that such positive results are due to international funds.

Other studies recognize non-statistically significant differences between sustainable and traditional fund performance during periods of crisis. Leite and Cortez [37] investigate the performance of one of the most relevant markets of sustainable funds in Europe-the French market—considering three crises: January 2001-March 2003, June 2007-February 2009, and May 2011-May 2012. Findings of the fourth-factor model reveal that the differences between sustainable and traditional funds are not significant during such market crises. Similarly, Matallín-Sáez et al. [60] test the resilience of US sustainable funds over the years 2000-2017, identifying two crisis periods: from April 2001 to November 2001 and from January 2008 to June 2009. Results obtained through the four-factor model [57] show that the outperformance of sustainable funds is non-statistically significant.

More recently, the COVID-19 pandemic has spurred research on sustainable investments and market shock, although findings remain inconclusive. Broadstock et al. [19], looking to Chinese firms, support the view that high ESG scores protect firm performance, while Folger-Laronde et al. [20] do not find evidence of any insurance role by high ESG scores when they analyze the relationship between ETF performance and Eco-fund ratings.

Given the inconsistency of previous findings, we pose the following alternative hypotheses:

Hypothesis 1a (H1a). Sustainable indexes are more resilient than traditional indexes during the COVID-19 lockdown announcements.

Hypothesis $\mathbf{1 b} \mathbf{( H 1 b ) . ~ S u s t a i n a b l e ~ i n d e x e s ~ a r e ~ n o t ~ m o r e ~ r e s i l i e n t ~ t h a n ~ t r a d i t i o n a l ~ i n d e x e s ~ d u r i n g ~}$ the COVID-19 lockdown announcements.

Among studies that focus on sustainable investments over periods of market downturns, few empirical studies investigate whether portfolio performance varies according to screening strategies used. Firms are generally selected according to one or more screening criteria: for instance, firms may be selected if they show good environmental, social and governance (ESG) performance (positive screening) or similarly if they show the best ESG performance of a definite set of companies (best in class), or if they are not involved with alcohol, tobacco, oil, gambling, etc. (negative screening) (for a review of screening, see: [7]). On a theoretical basis, it seems reasonable that a sustainable portfolio that applies only negative screening is less resilient than a portfolio of firms screened according to strong governance requirements [3,61] and showing an overall good reputation [37]. Indeed, strong governance may help firms during market downturns, and a good reputation should protect companies during periods of crisis [3,37].

There are only a few empirical studies, however, in this area, and they produce divergent results. For instance, Nofsinger and Varma [3] recognize that positive screeningcompared to negative screening - may encourage outperformance in times of crisis. In contrast with these findings, Leite and Cortez [37] analyzed sustainable funds that use positive screening and a combination of positive and negative screening strategies, concluding that there are no statistically significant differences between these investment strategies and their conventional peers during periods of crisis.

These considerations suggest that the resilience of sustainable strategies used by indexes is unclear; hence we formulate the following alternative hypotheses:

Hypothesis 2a (H2a). Sustainable indexes based on positive or best in class screening are more resilient than traditional peers. 
Hypothesis $\mathbf{2 b} \mathbf{( H 2 b ) . ~ S u s t a i n a b l e ~ i n d e x e s ~ b a s e d ~ o n ~ p o s i t i v e ~ o r ~ b e s t ~ i n ~ c l a s s ~ s c r e e n i n g ~ a r e ~ n o t ~}$ more resilient than traditional peers.

\section{Methods and Data}

\subsection{Methods}

To examine the impact of COVID-19 lockdown orders on sustainable indexes, we use the event study, and we relate our evidence to the traditional indexes. The event study has been widely adopted both to test the effect of new policy announcements on market prices (e.g., $[62,63])$ and to investigate the relationship between sustainable performance and financial performance (e.g., $[18,64])$. Furthermore, it has already been used to evaluate announcements related to the financial crisis, like during the Lehman bankruptcy [38], exceptional events like terroristic attacks (e.g., [65]), and more recently, it has been used to assess COVID-19 impact on traditional equity markets (e.g., $[29,30,33,66])$.

The event study allows us to test how much the index returns differ from the expected value on a set of days (event window). Thus, for any index, we calculate the abnormal return $(A R)$ as a difference between the return on index $i$ on the day $t$ and the expected return on index $\mathrm{i}$ on the day $\mathrm{t}$. The expected return is calculated through the market model [67] as a linear function of market return, here proxied by the MSCI World Index. The parameters $\alpha_{i}$ and $\beta_{i}$ are estimated over 260 trading days, starting from 31 December 2019.

To test if the COVID-19 lockdown orders generate effects over different days around the announcements, we calculate the cumulative abnormal return $\left(C A R_{i}\right) . C A R_{i}$ summarizes the effect on a set of short event windows- $[0 ; 0],[1 ; 0],[-1 ; 1]$ - to limit biased estimation caused by overlapping and confounding events (e.g., [68,69]). Then, to test the cumulative average effect on sustainable and traditional investments and on several different sustainable investment strategies, we calculate an average CAR, the cumulative average abnormal return (CAAR). Finally, to test the significance of CAAR, we use the Boehmer et al. [70] test (BMP). The BMP uses standardized abnormal returns, and it is robust to event-induced variance; consequently, the BMP is more prudent than other parametric tests, like the T-TEST [71,72].

As a first robustness test, we use the GRANK t-test by Kolari and Pynnönen [73]. This is a nonparametric test, so it takes into consideration the possibility that abnormal returns are not normally distributed, as supposed to parametric tests $[74,75]$. Moreover, the GRANK-T considers possible biases linked to event day clustering [73,75]. In our case, this is highly possible because the event day is the same for all indexes, and the hypothesis of cross-correlation independence could not be verified. As a second robustness test, we exclude from the analysis all the indexes aiming at reducing tracking error from the traditional family index. As third robustness and given the relevant variability of stock prices during the COVID-19 outbreak (e.g., [21]), we introduce the generalized autoregressive conditionally heteroskedastic (GARCH) approach [76] in the traditional market model. The market model [75] does not consider the heteroscedasticity of residuals, which are supposedly distributed as white noise (independent and identically distributed with a mean of zero). Thus, following the model specification of Savickas [77], we account for the time-varying variance of AR. CAARs are estimated as in the previous model, and the BMP test [70] is used to check the significance, as in Savickas [77].

Finally, we consider alternative events - the approval of policies aimed at mitigating the negative impact of COVID-19 lockdowns-to verify the reliability of our findings.

\subsection{Data}

To conduct our analysis, we use several sustainable indexes from the main index providers (Table 2), focusing on two main areas: Europe and the United States. These regions have a reasonable number of sustainable indexes $[1,40]$, so they appear highly representative of the overall sustainable investment market. Furthermore, Europe and the United States are widely affected by the COVID-19 pandemic and by the consequent crisis and policy announcements. 
Table 2. Indexes.

\begin{tabular}{|c|c|c|c|c|c|c|c|c|c|}
\hline \multirow{3}{*}{ Name } & \multirow{3}{*}{ Since } & \multicolumn{5}{|c|}{ Strategies } & \multirow[t]{3}{*}{ N. } & \multicolumn{2}{|c|}{ Family Peers } \\
\hline & & \multicolumn{2}{|c|}{ Selection } & \multicolumn{2}{|c|}{ Weighting } & \multirow{2}{*}{ MIN Tracking Error } & & \multirow{2}{*}{ Name } & \multirow{2}{*}{$\mathbf{N}$. } \\
\hline & & Negative & Best in Class & Capitalization & ESG & & & & \\
\hline MSCI Europe ESG Leaders & 2010 & YES & YES & YES & $\mathrm{NO}$ & NO & 218 & MSCI Europe & 438 \\
\hline MSCI Europe ESG Screened & 2018 & YES & NO & YES & NO & NO & 412 & MSCI Europe & 438 \\
\hline MSCI Europe SRI & 2011 & YES & YES & YES & NO & NO & 109 & MSCI Europe & 438 \\
\hline MSCI EMU Select ESG Rating and Trend Leaders & 2012 & YES & YES & YES & NO & $\mathrm{NO}$ & 138 & MSCI EMU & 244 \\
\hline S\&P Europe 350 ESG & 2010 & YES & YES & YES & $\mathrm{NO}$ & YES & 231 & S\&P Europe 350 & 350 \\
\hline Dow Jones Sustainability Europe & 2010 & NO & YES & YES & $\mathrm{NO}$ & $\mathrm{NO}$ & 144 & Stoxx Europe 600 & 600 \\
\hline $\begin{array}{l}\text { Dow Jones Sustainability Europe Index ex Alcohol, } \\
\text { Tobacco, Gambling, Armaments and Firearms }\end{array}$ & 2010 & YES & YES & YES & NO & NO & 122 & Stoxx Europe 600 & 600 \\
\hline EuroStoxx ESG Leaders & 2012 & YES & YES & $\mathrm{NO}$ & YES & $\mathrm{NO}$ & 50 & Stoxx Europe 600 & 600 \\
\hline Stoxx Europe ESG Leaders & 2012 & YES & YES & $\mathrm{NO}$ & YES & $\mathrm{NO}$ & 50 & Stoxx Europe 600 & 600 \\
\hline STOXX Europe 600 ESG-X & 2012 & YES & $\mathrm{NO}$ & YES & $\mathrm{NO}$ & YES & 538 & Stoxx Europe 600 & 600 \\
\hline FTSE4Good Europe & 2001 & YES & YES & YES & NO & NO & 413 & FTSE Europe & 588 \\
\hline MSCI USA ESG Leaders & 2010 & YES & YES & YES & $\mathrm{NO}$ & NO & 311 & MSCI United States & 633 \\
\hline MSCI USA ESG Screened & 2018 & YES & $\mathrm{NO}$ & YES & $\mathrm{NO}$ & $\mathrm{NO}$ & 595 & MSCI United States & 633 \\
\hline MSCI USA Extended ESG Focus & 2014 & YES & YES & $\mathrm{NO}$ & YES & YES & 308 & MSCI United States & 633 \\
\hline MSCI United States SRI & 2011 & YES & YES & YES & NO & NO & 149 & MSCI United States & 633 \\
\hline $\begin{array}{l}\text { MSCI United States Select ESG Rating and Trend } \\
\text { Leaders }\end{array}$ & 2018 & YES & YES & YES & NO & NO & 336 & MSCI United States & 633 \\
\hline S\&P USA 500 ESG & 2010 & YES & YES & $\mathrm{NO}$ & YES & YES & 311 & S\&P USA 500 & 500 \\
\hline Dow Jones Sustainability US Composite & 2005 & NO & YES & YES & NO & NO & 125 & S\&P USA 500 & 500 \\
\hline STOXX USA ESG Impact & 2010 & YES & YES & $\mathrm{NO}$ & YES & $\mathrm{NO}$ & 268 & STOXX USA 500 & 500 \\
\hline STOXX USA 500 ESG-X & 2012 & YES & $\mathrm{NO}$ & YES & $\mathrm{NO}$ & YES & 463 & STOXX USA 500 & 500 \\
\hline FTSE4Good US & 2001 & YES & YES & YES & NO & NO & 266 & FTSE USA & 608 \\
\hline
\end{tabular}


To test the resilience of sustainable indexes, we select the unexpected measures of lockdown, which included the public order to stay-at-home (Table 3). Similarly, we identify several measures adopted by Europe and the US to contrast the negative economic effects of the pandemic as alternative events (Table 3).

Data on index prices were retrieved from Refinitiv, while specifications on Indexes were selected from the Index web sites and/or Index methodologies and factsheets.

Table 3. COVID-19 outbreak: European and US policies.

\begin{tabular}{|c|c|c|}
\hline & & Europe \\
\hline Type of Event & Date & Policy \\
\hline \multirow[b]{2}{*}{ Negative events } & 23 February 2020 & $\begin{array}{l}\text { The first declaration of lockdown in Europe: lockdown in four } \\
\text { Italian cities }\end{array}$ \\
\hline & 9 March 2020 & $\begin{array}{l}\text { The first declaration of a country-lockdown in Europe: The Italian } \\
\text { declaration }\end{array}$ \\
\hline \multirow[b]{2}{*}{ Positive events } & 18 March 2020 & $\begin{array}{l}\text { The Council agreed on its position on legislative proposals, which will } \\
\text { free up funds from the EU } 2020 \text { budget to tackle the effects of the } \\
\text { COVID- } 19 \text { outbreak. The new measures will support SMEs and } \\
\text { strengthen investment in products and services necessary to bolster the } \\
\text { crisis response of health services. }\end{array}$ \\
\hline & 30 March 2020 & $\begin{array}{l}\text { The EU adopted legislation to quickly release funding from the EU } \\
\text { budget to tackle the COVID- } 19 \text { crisis. The legislation amends the rules of } \\
\text { the structural and investment funds to accommodate greater flexibility } \\
\text { and the release of } € 37 \text { billion for the Coronavirus Response Investment } \\
\text { Initiative. The EU also amended the scope of the EU Solidarity Fund to } \\
\text { include public health emergencies in addition to natural disasters. }\end{array}$ \\
\hline \multicolumn{3}{|r|}{ USA } \\
\hline Type of Event & Date & Policy \\
\hline \multirow[b]{2}{*}{ Negative events } & 29 February 2020 & The first declaration of lockdown: state of emergency Washington \\
\hline & 19 March 2020 & $\begin{array}{l}\text { The first declaration of lockdown: closure of all nonessential activities in } \\
\text { California }\end{array}$ \\
\hline \multirow{2}{*}{ Positive events } & 23 March 2020 & $\begin{array}{l}\text { FED securities purchase open end in the amount needed to support } \\
\text { market functioning and effective transmission of monetary policy to } \\
\text { broader financial conditions and economy. }\end{array}$ \\
\hline & 09 April 2020 & $\begin{array}{l}\text { Main street lending program. FED will fund up to } \$ 600 \text { billion in } 4 \\
\text { year loans }\end{array}$ \\
\hline
\end{tabular}

Source: authors' elaboration.

\section{Results and Discussion}

\subsection{Results on Sustainable Indexes}

Table 4 reports CAARs and statistical tests used to verify the impact of the COVID-19 outbreak on sustainable indexes. The analysis used traditional indexes as peers, and to enhance the comparability between the two groups of indexes, we introduced the mean difference between the two samples.

Results show that sustainable indexes obtained significant negative CAARs during the announcements of COVID lockdown orders both in Europe and in the USA (Table 4). Similarly, traditional indexes exhibit negative and significant CAARs. The mean difference between the two groups is slightly negative but not statistically significant. On the event date, the mean difference range between $-0.01 \%$ and $-0.12 \%$ in Europe and between $-0.05 \%$ and $-0.09 \%$ in the USA. The evidence on CAARs remains statistically significant also with the robustness test of GRANK-T [73]. In particular, the CAARs remain significant through the event windows $[0 ; 0]$ and $[0 ; 1]$, while they lose significance in $[-1 ; 1]$. 
Thus, our results seem to support the hypothesis that sustainable indexes were not more resilient than traditional indexes during the COVID-19 lockdowns. These results are in line with the findings of Leite and Cortez [37] and Matallín-Sáez et al. [60] on sustainable funds and with the recent research of Folger-Laronde et al. [20]. Although sustainable indexes do not appear to have had an insurance role [58] during the COVID-19 outbreak, the mean difference is not statistically significant; thus, financial-first investors may alternatively choose sustainable or traditional investments.

Table 4. Sustainable indexes resilience to COVID-19 lockdown.

\begin{tabular}{|c|c|c|c|c|c|c|c|c|c|}
\hline \multirow{3}{*}{ Date } & \multirow{3}{*}{$\begin{array}{c}\text { Event } \\
\text { Window }\end{array}$} & \multicolumn{3}{|c|}{ Sustainable Indexes } & \multicolumn{3}{|c|}{ Traditional Indexes } & \multirow{3}{*}{ Diff } & \multirow{3}{*}{$\begin{array}{c}p \text {-Value } \\
\text { Diff }\end{array}$} \\
\hline & & & BPM & GRANK-T & \multirow{2}{*}{ CAAR } & \multirow{2}{*}{$\begin{array}{c}\text { ВРМ } \\
p \text {-Value }\end{array}$} & \multirow{2}{*}{$\begin{array}{c}\text { GRANK-T } \\
p \text {-Value }\end{array}$} & & \\
\hline & & CAAR & $p$-Value & $p$-Value & & & & & \\
\hline \multicolumn{10}{|l|}{ Europe } \\
\hline \multirow{3}{*}{23.02 .2020} & {$[0 ; 0]$} & $-1.40 \%$ & 0.0000 & 0.0683 & $-1.39 \%$ & 0.0000 & 0.0603 & $-0.01 \%$ & 0.8818 \\
\hline & {$[0 ; 1]$} & $-1.07 \%$ & 0.0000 & 0.0727 & $-0.95 \%$ & 0.0000 & 0.0623 & $-0.12 \%$ & 0.4511 \\
\hline & {$[-1 ; 1]$} & $-0.55 \%$ & 0.0000 & 0.1371 & $-0.55 \%$ & 0.0055 & 0.1663 & $0.00 \%$ & 0.9934 \\
\hline \multirow{3}{*}{09.03 .2020} & {$[0 ; 0]$} & $-4.40 \%$ & 0.0000 & 0.0695 & $-4.29 \%$ & 0.0000 & 0.0603 & $-0.12 \%$ & 0.7570 \\
\hline & {$[0 ; 1]$} & $-2.41 \%$ & 0.0000 & 0.0695 & $-2.04 \%$ & 0.0000 & 0.0636 & $-0.38 \%$ & 0.1437 \\
\hline & {$[-1 ; 1]$} & $-3.22 \%$ & 0.0000 & 0.0683 & $-3.34 \%$ & 0.0000 & 0.0595 & $0.13 \%$ & 0.5778 \\
\hline \multicolumn{10}{|l|}{ USA } \\
\hline \multirow{3}{*}{ 29.02.2020 } & {$[0 ; 0]$} & $-1.01 \%$ & 0.0000 & 0.0570 & $-0.96 \%$ & 0.0000 & 0.0851 & $-0.05 \%$ & 0.5189 \\
\hline & {$[0 ; 1]$} & $-0.45 \%$ & 0.0000 & 0.0666 & $-0.38 \%$ & 0.0000 & 0.0851 & $-0.07 \%$ & 0.4421 \\
\hline & {$[-1 ; 1]$} & $0.00 \%$ & 0.8297 & 0.9801 & $0.08 \%$ & 0.0100 & 0.2016 & $-0.07 \%$ & 0.6366 \\
\hline \multirow{3}{*}{ 19.03.2020 } & {$[0 ; 0]$} & $-1.23 \%$ & 0.0000 & 0.0586 & $-1.14 \%$ & 0.0000 & 0.0851 & $-0.09 \%$ & 0.5230 \\
\hline & {$[0 ; 1]$} & $-0.56 \%$ & 0.0001 & 0.2282 & $-0.35 \%$ & 0.0000 & 0.0925 & $-0.21 \%$ & 0.3581 \\
\hline & {$[-1 ; 1]$} & $-0.91 \%$ & 0.0000 & 0.2011 & $-0.59 \%$ & 0.0000 & 0.0965 & $-0.32 \%$ & 0.3727 \\
\hline
\end{tabular}

The table illustrates the cumulative average abnormal returns (CAARs) obtained by sustainable and traditional indexes after the release of COVID-19 policies. Abnormal returns are calculated using the market model with an estimation period of 260 trading days, starting from 31 December 2019. The market portfolio is represented by the MSCI World Index. The statistical significance is tested through Boehmer et al.'s [70] test (BMP) and Kolari and Pynnönen's [73] test (GRANK-T). A two-sample $t$-test is used to test the significance of the mean difference in CAARs. Data referring to index prices are from Refinitiv.

\subsection{Results by Screening Strategies}

Table 5 represents sustainable index resilience over the COVID-19 outbreak distinguishing between different selection strategies of sustainable firms. Sustainable indexes identify a set of criteria-from negative to the best in class approach-used to compose the portfolio of companies [7]. We decided to also account for whether sustainable scores are used both to select firms and to attribute weights to index companies. Similar to the previous section, Table 5 reports CAARs and the statistical tests used to verify their significance. The mean difference and its statistical significance are calculated using traditional peers. Sustainable indexes in Europe and the US show negative and significant CAARs irrespectively of selection strategies. These results remain mainly significant using the GRANK $t$-test [73].

Our findings seem to discredit the hypothesis that selection strategies matter when evaluating the resiliency of sustainable indexes as the mean difference of the three groups of sustainable indexes was not statistically significant. The results do not change significantly if we group indexes that apply negative and best in class strategies without considering the mechanism of weighting firms (results are available upon request).

Our empirical results seem to fall in line with findings of Leite and Cortez [37], which, in contrast to Nofsinger and Varma [3], support the idea that sustainable funds that adopt positive screening fail to "offer any additional support to investors relative to conventional funds". However, we need to be careful when interpreting our results because sustainable indexes mainly use a negative screening strategy in combination with other strategies (Table 2). Furthermore, the analysis of indexes adopting negative screening strategies is limited to MSCI Europe ESG screened and Stoxx Europe 600 ESG-X in Europe and to MSCI USA ESG Screened and Stoxx USA 500 ESG-X in the USA, respectively. 
Table 5. Sustainable indexes by selection strategies: resilience to COVID-19.

\begin{tabular}{|c|c|c|c|c|c|c|c|c|c|c|c|c|c|c|c|c|}
\hline \multirow{3}{*}{ Date } & \multirow{3}{*}{$\begin{array}{c}\text { Event } \\
\text { Window }\end{array}$} & \multicolumn{5}{|c|}{ Negative and Best in Class } & \multicolumn{5}{|c|}{ Negative } & \multicolumn{5}{|c|}{ Negative and Best in Class and ESG Weight } \\
\hline & & \multirow{2}{*}{ CAAR } & \multirow{2}{*}{$\begin{array}{c}\text { BPM } \\
p \text {-Value }\end{array}$} & \multirow{2}{*}{$\begin{array}{c}\text { Grank-T } \\
p \text {-Value }\end{array}$} & \multirow{2}{*}{ Diff } & \multirow{2}{*}{$\begin{array}{c}p \text {-Value } \\
\text { Diff }\end{array}$} & \multirow{2}{*}{ CAAR } & \multirow{2}{*}{$\begin{array}{c}\text { ВРМ } \\
p \text {-Value }\end{array}$} & \multirow{2}{*}{$\begin{array}{c}\text { Grank-T } \\
p \text {-Value } \\
\end{array}$} & \multirow{2}{*}{ Diff } & \multirow{2}{*}{$\begin{array}{c}p \text {-Value } \\
\text { Diff }\end{array}$} & \multirow{2}{*}{ CAAR } & \multirow{2}{*}{$\begin{array}{c}\text { ВРМ } \\
p \text {-Value }\end{array}$} & \multirow{2}{*}{$\begin{array}{c}\text { Grank-T } \\
p \text {-Value } \\
\end{array}$} & \multirow{2}{*}{ Diff } & \multirow{2}{*}{$\begin{array}{c}p \text {-Value } \\
\text { Diff }\end{array}$} \\
\hline & & & & & & & & & & & & & & & & \\
\hline \multicolumn{17}{|l|}{ Europe } \\
\hline \multirow{3}{*}{ 23.02.2020 } & {$[0 ; 0]$} & $-1.41 \%$ & 0.0000 & 0.0733 & $-0.02 \%$ & 0.7978 & $-1.37 \%$ & 0.0000 & 0.0756 & $0.02 \%$ & 0.8314 & $-1.34 \%$ & 0.0000 & 0.0824 & $0.05 \%$ & 0.7155 \\
\hline & {$[0 ; 1]$} & $-1.13 \%$ & 0.0000 & 0.0756 & $-0.18 \%$ & 0.2502 & $-0.82 \%$ & 0.0000 & 0.0756 & $0.14 \%$ & 0.4758 & $-0.88 \%$ & 0.0002 & 0.0898 & $0.08 \%$ & 0.7316 \\
\hline & {$[-1 ; 1]$} & $-0.62 \%$ & 0.0000 & 0.1008 & $-0.07 \%$ & 0.7570 & $-0.28 \%$ & 0.0006 & 0.0915 & $0.27 \%$ & 0.4344 & $-0.35 \%$ & 0.1492 & 0.2529 & $0.21 \%$ & 0.5683 \\
\hline \multirow{2}{*}{ 09.03.2020 } & {$[0 ; 0]$} & $-4.15 \%$ & 0.0000 & 0.0733 & $0.14 \%$ & 0.6653 & $-4.44 \%$ & 0.0000 & 0.0767 & $-0.15 \%$ & 0.7838 & $-5.51 \%$ & 0.0000 & 0.0800 & $-1.23 \%$ & 0.0601 \\
\hline & {$[-1 ; 1]$} & $-3.12 \%$ & 0.0000 & 0.0733 & $0.22 \%$ & 0.2904 & $-3.03 \%$ & 0.0000 & 0.0756 & $0.32 \%$ & 0.3769 & $-3.85 \%$ & 0.0000 & 0.0800 & $-0.51 \%$ & 0.1694 \\
\hline \multicolumn{17}{|l|}{ USA } \\
\hline \multirow{3}{*}{29.02 .2020} & {$[0 ; 0]$} & $-0.98 \%$ & 0.0000 & 0.0599 & $-0.02 \%$ & 0.7416 & $-0.96 \%$ & 0.0000 & 0.0850 & $-0.01 \%$ & 0.7969 & $-1.01 \%$ & 0.0000 & 0.0633 & $-0.05 \%$ & 0.6179 \\
\hline & {$[0 ; 1]$} & $-0.40 \%$ & 0.0003 & 0.1004 & $-0.02 \%$ & 0.8790 & $-0.52 \%$ & 0.0000 & 0.0850 & $-0.14 \%$ & 0.4846 & $-0.48 \%$ & 0.0000 & 0.0647 & $-0.10 \%$ & 0.5638 \\
\hline & {$[-1 ; 1]$} & $0.06 \%$ & 0.6583 & 0.8637 & $-0.02 \%$ & 0.8869 & $-0.15 \%$ & 0.0312 & 0.1585 & $-0.23 \%$ & 0.5174 & $0.00 \%$ & 0.8012 & 0.7388 & $-0.08 \%$ & 0.5441 \\
\hline \multirow{3}{*}{19.03 .2020} & {$[0 ; 0]$} & $-1.41 \%$ & 0.0000 & 0.0599 & $-0.27 \%$ & 0.0997 & $-0.89 \%$ & 0.0000 & 0.0850 & $0.25 \%$ & 0.1097 & $-1.24 \%$ & 0.0000 & 0.0711 & $-0.10 \%$ & 0.6357 \\
\hline & [0;1] & $-0.84 \%$ & 0.0000 & 0.0619 & $-0.49 \%$ & 0.0399 & $0.15 \%$ & 0.2814 & 0.4044 & $0.50 \%$ & 0.1659 & $-0.53 \%$ & 0.0000 & 0.0660 & $-0.18 \%$ & 0.2945 \\
\hline & {$[-1 ; 1]$} & $-1.28 \%$ & 0.0000 & 0.0575 & $-0.69 \%$ & 0.0606 & $0.21 \%$ & 0.1699 & 0.2778 & $0.80 \%$ & 0.1722 & $-1.08 \%$ & 0.0000 & 0.0633 & $-0.49 \%$ & 0.1631 \\
\hline
\end{tabular}

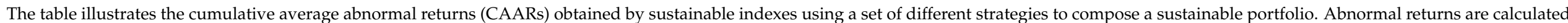

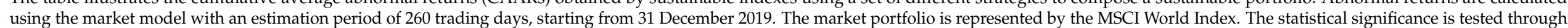

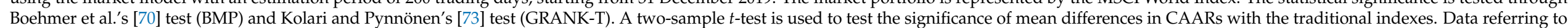
index prices are from Refinitiv. 


\subsection{Results Excluding Tracking Error Optimizations}

Some sustainable indexes included in our analysis declare they aim to reduce tracking error with traditional indexes; thus, Table 6 presents CAARs and the mean difference of both sustainable indexes that do not use tracking error and traditional indexes. During the announcements of the COVID lockdown orders, sustainable indexes in Europe show a slightly negative but not statistically significant mean difference, ranging from $0.00 \%$ and $-0.12 \%$ in the event window [0;0]. Similarly, sustainable indexes in the US show a mean difference between $-0.08 \%$ and $-0.12 \%$.

The evidence confirms previous findings, both in European and US markets. Consequently, sustainable indexes that do not aim to reduce tracking error with their family indexes do not appear more resilient to the COVID-19 crisis than traditional ones. Such results are also robust in the GRANK $t$-test.

Table 6. Results excluding indexes that aim to reduce tracking error.

\begin{tabular}{|c|c|c|c|c|c|c|c|c|c|}
\hline \multirow{3}{*}{ Date } & \multirow{3}{*}{$\begin{array}{c}\text { Event } \\
\text { Window }\end{array}$} & \multicolumn{3}{|c|}{$\begin{array}{l}\text { Sustainable Indexes } \\
\text { (No Tracking Error) }\end{array}$} & \multicolumn{3}{|c|}{ Traditional Indexes } & \multirow{3}{*}{ Diff } & \multirow{3}{*}{$\begin{array}{c}p \text {-Value } \\
\text { Diff }\end{array}$} \\
\hline & & \multirow{2}{*}{ CAAR } & BPM & Grank-T & \multirow{2}{*}{ CAAR } & \multirow{2}{*}{$\begin{array}{c}\text { ВРМ } \\
p \text {-Value }\end{array}$} & \multirow{2}{*}{$\begin{array}{l}\text { Grank-T } \\
p \text {-Value }\end{array}$} & & \\
\hline & & & $p$-Value & $p$-Value & & & & & \\
\hline \multicolumn{10}{|l|}{ Europe } \\
\hline \multirow{3}{*}{23.02 .2020} & {$[0 ; 0]$} & $-1.39 \%$ & 0.0000 & 0.0685 & $-1.39 \%$ & 0.0000 & 0.0603 & $0.00 \%$ & 0.9796 \\
\hline & {$[0 ; 1]$} & $-1.08 \%$ & 0.0000 & 0.0732 & $-0.95 \%$ & 0.0000 & 0.0623 & $-0.13 \%$ & 0.4435 \\
\hline & {$[-1 ; 1]$} & $-0.55 \%$ & 0.0000 & 0.1334 & $-0.55 \%$ & 0.0055 & 0.1663 & $0.00 \%$ & 0.9934 \\
\hline \multirow{3}{*}{ 09.03.2020 } & {$[0 ; 0]$} & $-4.41 \%$ & 0.0000 & 0.0693 & $-4.29 \%$ & 0.0000 & 0.0603 & $-0.12 \%$ & 0.7550 \\
\hline & {$[0 ; 1]$} & $-2.44 \%$ & 0.0000 & 0.0693 & $-2.04 \%$ & 0.0000 & 0.0636 & $-0.40 \%$ & 0.1473 \\
\hline & {$[-1 ; 1]$} & $-3.23 \%$ & 0.0000 & 0.0681 & $-3.34 \%$ & 0.0000 & 0.0595 & $0.12 \%$ & 0.6459 \\
\hline \multicolumn{10}{|l|}{ USA } \\
\hline \multirow{3}{*}{29.02 .2020} & {$[0 ; 0]$} & $-1.03 \%$ & 0.0000 & 0.0529 & $-0.96 \%$ & 0.0000 & 0.0851 & $-0.08 \%$ & 0.3767 \\
\hline & {$[0 ; 1]$} & $-0.47 \%$ & 0.0000 & 0.0700 & $-0.38 \%$ & 0.0000 & 0.0851 & $-0.09 \%$ & 0.3784 \\
\hline & {$[-1 ; 1]$} & $-0.05 \%$ & 0.7646 & 0.8065 & $0.08 \%$ & 0.0100 & 0.2016 & $-0.13 \%$ & 0.4750 \\
\hline \multirow{3}{*}{ 19.03.2020 } & {$[0 ; 0]$} & $-1.26 \%$ & 0.0000 & 0.0553 & $-1.14 \%$ & 0.0000 & 0.0851 & $-0.12 \%$ & 0.4596 \\
\hline & {$[0 ; 1]$} & $-0.70 \%$ & 0.0000 & 0.1361 & $-0.35 \%$ & 0.0000 & 0.0925 & $-0.35 \%$ & 0.1076 \\
\hline & {$[-1 ; 1]$} & $-1.11 \%$ & 0.0000 & 0.1175 & $-0.59 \%$ & 0.0000 & 0.0965 & $-0.52 \%$ & 0.1285 \\
\hline
\end{tabular}

The table illustrates the cumulative average abnormal returns (CAARs) obtained after the release of COVID-19 policies by (i) sustainable indexes excluding indexes that aim to reduce tracking error with their family index; (ii) traditional indexes. Abnormal returns are calculated using the market model with an estimation period of 260 trading days, starting from 31 December 2019. The market portfolio is represented by the MSCI World Index. The statistical significance is tested through Boehmer et al.'s [70] test (BMP) and Kolari and Pynnönen's [73] test (GRANK-T). A two-sample $t$-test is used to test the significance of mean differences in CAARs. Data referring to index prices are from Refinitiv.

\subsection{Empirical Result Estimations with GARCH Model}

Table 7 introduces the results of the GARCH robustness test. In order to account for possible biases that may result from not accounting for the time-varying variance of AR, we estimate our model, including the GARCH $(1,1)$ specification [77].

As for the previous robustness tests, the GARCH estimation shows a negative impact of the COVID-19 lockdown on sustainable indexes. The mean difference in the event window [0;0] ranged from $-0.01 \%$ to $-0.11 \%$ in Europe and from $-0.03 \%$ to $-0.12 \%$ in the USA. Thus, our results remain valid, also using an alternative model to estimate ARthe GARCH market model-confirming that lockdown announcements generate slightly negative but no significant differences between the two groups of CAARs.

Similarly, our estimation on sustainable strategies remains robust to the GARCH market model (for the sake of brevity, we do not include the table, but results are available upon request). 
Table 7. Event study with generalized autoregressive conditionally heteroskedastic (GARCH).

\begin{tabular}{|c|c|c|c|c|c|c|c|}
\hline \multirow{3}{*}{ Date } & \multirow{3}{*}{$\begin{array}{c}\text { Event } \\
\text { Window }\end{array}$} & \multicolumn{2}{|c|}{ Sustainable Indexes } & \multicolumn{2}{|c|}{ Traditional Indexes } & \multirow{3}{*}{ Diff } & \multirow{3}{*}{$p$-Value Diff } \\
\hline & & CAAR & BPM & CAAR & BPM & & \\
\hline & & Сละก & $p$-Value & CดAก & $p$-Value & & \\
\hline \multicolumn{8}{|l|}{ Europe } \\
\hline \multirow{3}{*}{23.02 .2020} & {$[0 ; 0]$} & $-0.81 \%$ & 0.0000 & $-0.80 \%$ & 0.0000 & $-0.01 \%$ & 0.9217 \\
\hline & {$[0 ; 1]$} & $0.08 \%$ & 0.0443 & $0.20 \%$ & 0.4980 & $-0.13 \%$ & 0.6534 \\
\hline & {$[-1 ; 1]$} & $0.77 \%$ & 0.0000 & $0.78 \%$ & 0.0046 & $0.00 \%$ & 0.9888 \\
\hline \multirow{3}{*}{ 09.03.2020 } & {$[0 ; 0]$} & $-4.89 \%$ & 0.0000 & $-4.78 \%$ & 0.0000 & $-0.11 \%$ & 0.6959 \\
\hline & {$[0 ; 1]$} & $-2.04 \%$ & 0.0000 & $-1.66 \%$ & 0.0000 & $-0.39 \%$ & 0.2602 \\
\hline & {$[-1 ; 1]$} & $-1.33 \%$ & 0.0000 & $-1.49 \%$ & 0.0000 & $0.15 \%$ & 0.5790 \\
\hline \multicolumn{8}{|l|}{ USA } \\
\hline \multirow{3}{*}{ 29.02.2020 } & {$[0 ; 0]$} & $-1.16 \%$ & 0.0000 & $-1.13 \%$ & 0.0000 & $-0.03 \%$ & 0.4591 \\
\hline & {$[0 ; 1]$} & $-0.41 \%$ & 0.0000 & $-0.32 \%$ & 0.0000 & $-0.09 \%$ & 0.3485 \\
\hline & {$[-1 ; 1]$} & $0.26 \%$ & 0.0002 & $0.41 \%$ & 0.0000 & $-0.14 \%$ & 0.5675 \\
\hline \multirow{3}{*}{ 19.03.2020 } & {$[0 ; 0]$} & $-0.29 \%$ & 0.0216 & $-0.18 \%$ & 0.0012 & $-0.12 \%$ & 0.5140 \\
\hline & {$[0 ; 1]$} & $-1.82 \%$ & 0.0000 & $-1.64 \%$ & 0.0000 & $-0.18 \%$ & 0.4166 \\
\hline & {$[-1 ; 1]$} & $-0.97 \%$ & 0.0160 & $-1.10 \%$ & 0.0000 & $0.14 \%$ & 0.3357 \\
\hline
\end{tabular}

The table illustrates the cumulative average abnormal returns (CAARs) obtained by sustainable and traditional indexes after the release of COVID-19 policies. Abnormal returns are calculated using the market model with GARCH $(1,1)$ specifications and through an estimation period of 260 trading days, starting from 31 December 2019. The market portfolio is represented by the MSCI World Index. The statistical significance is tested through Boehmer et al.'s [70] test (BMP). A two-sample $t$-test is used to test the significance of mean differences in CAARs. Data referring to index prices are from Refinitiv.

\subsection{Alternative Events}

Finally, to test the resilience of sustainable indexes during the COVID-19 outbreak, we use alternative events. Specifically, we chose to select positive announcements, first, because previous literature supports that the opposing nature of announcements may have a different effect on sustainable stock returns (e.g., for a review: [18]). Second, major market shocks over the COVID-19 crisis occurred both during the announcements of negative events (such as the lockdown orders) and positive events [21]. Thus, we use governmental measures announced to mitigate the negative economic and financial effects of the COVID19 pandemic (Table 3) to test whether the resilience of sustainable and traditional indexes does not differ significantly.

Table 8 presents our robustness test considering all the model specifications considered to now. Policies for contrasting the negative economic impact of the COVID lockdown generated different effects in Europe and the USA. Specifically, CAARs of both sustainable and traditional indexes were mainly negative in Europe and mainly positive in the USA (Table 8). Such diversified effects may be explained by the different magnitude of government actions. There was indeed a large liquidity injection into the US market, and in turn, the European market seems to have penalized the slow and relatively limited support to the European economy. In any case, in Europe, the differences between CAARs of sustainable and traditional indexes are slightly positive (between $0.17 \%$ and $0.44 \%$ in the event window $[0 ; 0])$ although not statistically significant. On the other hand, in the USA, the differences are slightly negative (between $-0.10 \%$ and $-0.12 \%$ ) and not statistically significant (Table 8 ). These findings are also confirmed when we consider sustainable indexes that do not aim to reduce tracking error (Table 8) and by the GARCH estimation (Table 9). The analysis of alternative events also confirms the results on sustainable strategies (Table 10).

Overall, the analysis of alternative-positive events shows that also during the announcements of positive events related to the COVID-19 crisis, there were no statistically significant differences between sustainable and traditional indexes. 
Table 8. Sustainable indexes resilience under COVID-19 economic policies.

\begin{tabular}{|c|c|c|c|c|c|c|c|c|c|c|c|c|c|c|}
\hline \multirow{3}{*}{ Date } & \multirow{3}{*}{$\begin{array}{c}\text { Event } \\
\text { Window }\end{array}$} & \multicolumn{3}{|c|}{ Sustainable Indexes } & \multicolumn{3}{|c|}{ Sustainable Indexes (No Tracking Error) } & \multicolumn{3}{|c|}{ Traditional Indexes } & \multicolumn{2}{|c|}{$\begin{array}{l}\text { Sustainable vs. Traditional } \\
\text { Indexes }\end{array}$} & \multicolumn{2}{|c|}{$\begin{array}{l}\text { Sustainable (no Tracking Error) } \\
\text { vs. Traditional Indexes }\end{array}$} \\
\hline & & \multirow{2}{*}{ CAAR } & BPM & GRANK-T & \multirow{2}{*}{ CAAR } & \multirow{2}{*}{$\begin{array}{c}\text { BPM } \\
p \text {-Value }\end{array}$} & \multirow{2}{*}{$\begin{array}{c}\text { Grank-T } \\
p \text {-Value } \\
\end{array}$} & \multirow{2}{*}{ CAAR } & \multirow{2}{*}{$\begin{array}{c}\text { BPM } \\
p \text {-Value }\end{array}$} & \multirow{2}{*}{$\begin{array}{c}\text { GRANK-T } \\
p \text {-Value }\end{array}$} & \multirow{2}{*}{ Diff } & \multirow{2}{*}{$\begin{array}{c}p \text {-Value } \\
\text { Diff }\end{array}$} & \multirow{2}{*}{ Diff } & \multirow{2}{*}{$p$-Value Diff } \\
\hline & & & $p$-Value & $p$-Value & & & & & & & & & & \\
\hline \multicolumn{15}{|l|}{ Europe } \\
\hline \multirow{3}{*}{ 18.03.2020 } & {$[0 ; 0]$} & $-0.81 \%$ & 0.0000 & 0.1118 & $-0.80 \%$ & 0.0000 & 0.1161 & $-0.99 \%$ & 0.0001 & 0.1513 & $0.17 \%$ & 0.4865 & $0.18 \%$ & 0.4898 \\
\hline & {$[0 ; 1]$} & $0.08 \%$ & 0.4364 & 0.8136 & $0.10 \%$ & 0.4145 & 0.7766 & $0.08 \%$ & 0.8395 & 0.8940 & $0.00 \%$ & 0.9959 & $0.02 \%$ & 0.9664 \\
\hline & {$[-1 ; 1]$} & $-1.87 \%$ & 0.0000 & 0.0913 & $-1.79 \%$ & 0.0000 & 0.0956 & $-1.95 \%$ & 0.0268 & 0.2806 & $0.08 \%$ & 0.9091 & $0.16 \%$ & 0.8307 \\
\hline \multirow[b]{2}{*}{30.03 .2020} & {$[0 ; 0]$} & $-0.85 \%$ & 0.0000 & 0.2184 & $-0.82 \%$ & 0.0003 & 0.2598 & $-1.28 \%$ & 0.0000 & 0.0771 & $0.44 \%$ & 0.2213 & $0.47 \%$ & 0.2340 \\
\hline & {$[0 ; 1]$} & $0.93 \%$ & 0.0000 & 0.1683 & $0.93 \%$ & 0.0000 & 0.2011 & $0.83 \%$ & 0.0082 & 0.2291 & $0.10 \%$ & 0.7685 & $0.09 \%$ & 0.8057 \\
\hline \multicolumn{15}{|l|}{ USA } \\
\hline \multirow{3}{*}{ 23.03.2020 } & {$[0 ; 0]$} & $0.67 \%$ & 0.0000 & 0.0904 & $0.56 \%$ & 0.0000 & 0.0901 & $0.79 \%$ & 0.0000 & 0.0827 & $-0.12 \%$ & 0.4341 & $-0.23 \%$ & 0.1181 \\
\hline & {$[0 ; 1]$} & $-0.51 \%$ & 0.0000 & 0.1500 & $-0.51 \%$ & 0.0008 & 0.2120 & $-0.56 \%$ & 0.0000 & 0.0851 & $0.05 \%$ & 0.7722 & $0.05 \%$ & 0.8084 \\
\hline & {$[-1 ; 1]$} & $-1.75 \%$ & 0.0000 & 0.0576 & $-1.77 \%$ & 0.0000 & 0.0539 & $-1.70 \%$ & 0.0000 & 0.0851 & $-0.05 \%$ & 0.7709 & $-0.07 \%$ & 0.6858 \\
\hline \multirow{3}{*}{09.04 .2020} & & $-0.55 \%$ & 0.0000 & 0.0593 & $-0.56 \%$ & 0.0000 & 0.0578 & $-0.44 \%$ & 0.0000 & 0.0851 & $-0.10 \%$ & 0.1588 & $-0.12 \%$ & 0.1437 \\
\hline & {$[0 ; 1]$} & $-0.62 \%$ & 0.0000 & 0.0932 & $-0.66 \%$ & 0.0000 & 0.1089 & $-0.62 \%$ & 0.0000 & 0.0851 & $0.00 \%$ & 0.9955 & $-0.04 \%$ & 0.7971 \\
\hline & {$[-1 ; 1]$} & $-0.27 \%$ & 0.0000 & 0.1588 & $-0.32 \%$ & 0.0000 & 0.1327 & $-0.11 \%$ & 0.0024 & 0.1738 & $-0.15 \%$ & 0.1439 & $-0.21 \%$ & 0.1676 \\
\hline
\end{tabular}

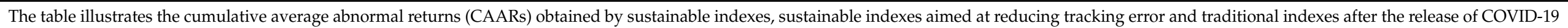

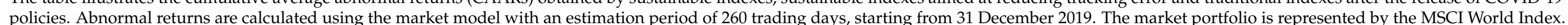

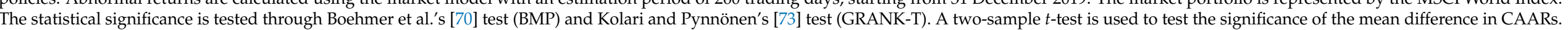
Data referring to index prices are from Refinitiv. 
Table 9. Event study with GARCH: impact of COVID-19 positive announcements.

\begin{tabular}{|c|c|c|c|c|c|c|c|}
\hline \multirow{3}{*}{ Date } & \multirow{3}{*}{ Event Window } & \multicolumn{2}{|c|}{ Sustainable Indexes } & \multicolumn{2}{|c|}{ Traditional Indexes } & \multirow{3}{*}{ Diff } & \multirow{3}{*}{$p$-Value Diff } \\
\hline & & & ВРM & & BPM & & \\
\hline & & CAAN & $p$-Value & САAK & $p$-Value & & \\
\hline \multicolumn{8}{|l|}{ Europe } \\
\hline \multirow{3}{*}{ 18.03.2020 } & {$[0 ; 0]$} & $0.24 \%$ & 0.0756 & $0.06 \%$ & 0.7651 & $0.18 \%$ & 0.4355 \\
\hline & {$[0 ; 1]$} & $1.02 \%$ & 0.0000 & $1.00 \%$ & 0.1090 & $0.02 \%$ & 0.9944 \\
\hline & {$[-1 ; 1]$} & $-1.60 \%$ & 0.0000 & $-1.70 \%$ & 0.0013 & $0.10 \%$ & 0.8996 \\
\hline \multirow{3}{*}{30.03 .2020} & {$[0 ; 0]$} & $-1.24 \%$ & 0.0000 & $-1.68 \%$ & 0.0000 & $0.44 \%$ & 0.2186 \\
\hline & {$[0 ; 1]$} & $0.76 \%$ & 0.2719 & $0.65 \%$ & 0.9934 & $0.11 \%$ & 0.6745 \\
\hline & {$[-1 ; 1]$} & $0.62 \%$ & 0.3334 & $0.14 \%$ & 0.1586 & $0.49 \%$ & 0.2613 \\
\hline \multicolumn{8}{|l|}{ USA } \\
\hline \multirow{3}{*}{ 23.03.2020 } & {$[0 ; 0]$} & $0.43 \%$ & 0.0000 & $0.51 \%$ & 0.0000 & $-0.08 \%$ & 0.4166 \\
\hline & {$[0 ; 1]$} & $-0.09 \%$ & 0.3293 & $-0.04 \%$ & 0.0000 & $-0.05 \%$ & 0.7665 \\
\hline & {$[-1 ; 1]$} & $-1.61 \%$ & 0.0000 & $-1.50 \%$ & 0.0000 & $-0.11 \%$ & 0.6975 \\
\hline \multirow[b]{2}{*}{09.04 .2020} & {$[0 ; 0]$} & $-0.42 \%$ & 0.0000 & $-0.30 \%$ & 0.0000 & $-0.12 \%$ & 0.2343 \\
\hline & {$[0 ; 1]$} & $-0.36 \%$ & 0.0000 & $-0.30 \%$ & 0.0000 & $-0.05 \%$ & 0.8956 \\
\hline
\end{tabular}

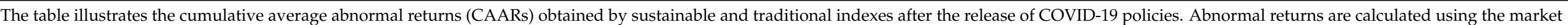

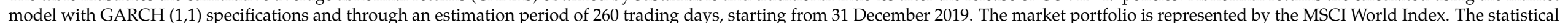
significance is tested through Boehmer et al.'s [70] test (BMP). A two-sample $t$-test is used to test the significance of mean differences in CAARs. Data referring to index prices are from Refinitiv. 
Table 10. Sustainable indexes by selection strategies: impact of positive COVID-19 announcements.

\begin{tabular}{|c|c|c|c|c|c|c|c|c|c|c|c|c|c|c|c|c|}
\hline \multirow{3}{*}{ Date } & \multirow{3}{*}{$\begin{array}{c}\text { Event } \\
\text { Window }\end{array}$} & \multicolumn{5}{|c|}{ Negative and Best in Class } & \multicolumn{5}{|c|}{ Negative } & \multicolumn{5}{|c|}{ Negative and Best in Class and ESG Weight } \\
\hline & & \multirow{2}{*}{ CAAR } & BPM & Grank-T & \multirow{2}{*}{ Diff } & \multirow{2}{*}{$\begin{array}{c}\text { p-Value } \\
\text { Diff }\end{array}$} & \multirow{2}{*}{ CAAR } & \multirow{2}{*}{$\begin{array}{c}\text { BPM } \\
p \text {-Value }\end{array}$} & \multirow{2}{*}{$\begin{array}{l}\text { Grank-T } \\
p \text {-Value }\end{array}$} & \multirow{2}{*}{ Diff } & \multirow{2}{*}{$\begin{array}{c}p \text {-Value } \\
\text { Diff }\end{array}$} & \multirow{2}{*}{ CAAR } & \multirow{2}{*}{$\frac{\text { BPM }}{p \text {-Value }}$} & \multirow{2}{*}{$\begin{array}{c}\text { Grank-T } \\
p \text {-Value }\end{array}$} & \multirow{2}{*}{ Diff } & \multirow{2}{*}{$\begin{array}{c}p \text {-Value } \\
\text { Diff }\end{array}$} \\
\hline & & & $p$-Value & $p$-Value & & & & & & & & & & & & \\
\hline \multicolumn{17}{|l|}{ Europe } \\
\hline \multirow{3}{*}{18.03 .2020} & {$[0 ; 0]$} & $-0.96 \%$ & 0.0000 & 0.0806 & $0.02 \%$ & 0.9290 & $-0.70 \%$ & 0.0006 & 0.0915 & $0.28 \%$ & 0.5482 & $-0.25 \%$ & 0.0015 & 0.1020 & $0.74 \%$ & 0.1450 \\
\hline & {$[0 ; 1]$} & $0.12 \%$ & 0.4340 & 0.8185 & $0.04 \%$ & 0.8419 & $0.04 \%$ & 0.9038 & 0.9619 & $-0.04 \%$ & 0.8754 & $-0.10 \%$ & 0.8373 & 0.9036 & $-0.18 \%$ & 0.5574 \\
\hline & {$[-1 ; 1]$} & $-1.88 \%$ & 0.0000 & 0.0989 & $0.07 \%$ & 0.8593 & $-2.35 \%$ & 0.0000 & 0.0779 & $-0.40 \%$ & 0.3683 & $-1.69 \%$ & 0.0554 & 0.1742 & $0.26 \%$ & 0.6779 \\
\hline \multirow{3}{*}{30.03 .2020} & {$[0 ; 0]$} & $-0.66 \%$ & 0.0111 & 0.3116 & $0.63 \%$ & 0.1360 & $-1.06 \%$ & 0.0000 & 0.0779 & $0.22 \%$ & 0.6677 & $-1.56 \%$ & 0.0000 & 0.0800 & $-0.28 \%$ & 0.5886 \\
\hline & {$[0 ; 1]$} & $1.16 \%$ & 0.0000 & 0.0885 & $0.33 \%$ & 0.1864 & $0.86 \%$ & 0.0000 & 0.0734 & $0.03 \%$ & 0.8874 & $0.02 \%$ & 0.8831 & 0.9356 & $-0.82 \%$ & 0.0084 \\
\hline & {$[-1 ; 1]$} & $0.48 \%$ & 0.0541 & 0.4243 & $0.68 \%$ & 0.0672 & $0.23 \%$ & 0.5635 & 0.6720 & $0.43 \%$ & 0.3077 & $-0.72 \%$ & 0.0079 & 0.1153 & $-0.52 \%$ & 0.1978 \\
\hline \multicolumn{17}{|l|}{ USA } \\
\hline \multirow{3}{*}{ 23.03.2020 } & {$[0 ; 0]$} & $0.57 \%$ & 0.0000 & 0.0706 & $-0.22 \%$ & 0.2154 & $1.04 \%$ & 0.0000 & 0.0826 & $0.25 \%$ & 0.2284 & $0.72 \%$ & 0.0000 & 0.0750 & $-0.08 \%$ & 0.1403 \\
\hline & {$[0 ; 1]$} & $-0.35 \%$ & 0.1485 & 0.4302 & $0.21 \%$ & 0.4802 & $-0.54 \%$ & 0.0000 & 0.0850 & $0.02 \%$ & 0.9173 & $-0.61 \%$ & 0.0000 & 0.0633 & $-0.05 \%$ & 0.6301 \\
\hline & {$[-1 ; 1]$} & $-1.76 \%$ & 0.0000 & 0.0614 & $-0.06 \%$ & 0.7688 & $-1.43 \%$ & 0.0000 & 0.0850 & $0.27 \%$ & 0.4474 & $-1.86 \%$ & 0.0000 & 0.0633 & $-0.15 \%$ & 0.6416 \\
\hline \multirow{3}{*}{09.04 .2020} & {$[0 ; 0]$} & $-0.54 \%$ & 0.0000 & 0.0771 & $-0.09 \%$ & 0.3141 & $-0.56 \%$ & 0.0000 & 0.0850 & $-0.12 \%$ & 0.0058 & $-0.51 \%$ & 0.0000 & 0.0633 & $-0.07 \%$ & 0.4899 \\
\hline & {$[0 ; 1]$} & $-0.70 \%$ & 0.0001 & 0.0989 & $-0.09 \%$ & 0.8849 & $-0.61 \%$ & 0.0000 & 0.0850 & $0.01 \%$ & 0.9560 & $-0.40 \%$ & 0.0093 & 0.1534 & $0.22 \%$ & 0.3833 \\
\hline & {$[-1 ; 1]$} & $-0.43 \%$ & 0.0000 & 0.0765 & $-0.31 \%$ & 0.2990 & $-0.19 \%$ & 0.0005 & 0.0977 & $-0.07 \%$ & 0.8301 & $-0.09 \%$ & 0.1714 & 0.3865 & $0.03 \%$ & 0.9714 \\
\hline
\end{tabular}

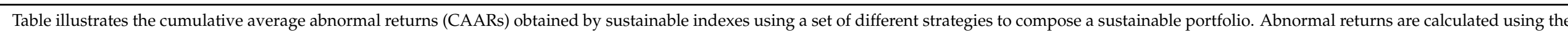

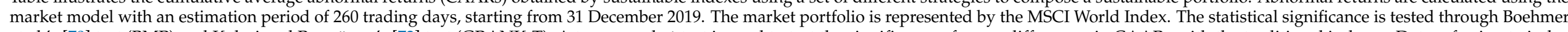

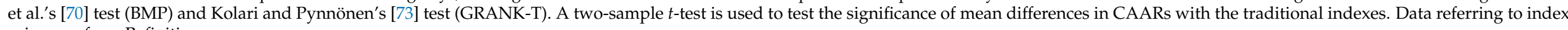
prices are from Refinitiv. 


\section{Conclusions}

Our study contributes to the recent research on the COVID-19 outbreak (e.g., [29,30,33]), shedding light on the sustainability market and on the relatively unexplored field of sustainable indexes and market shocks. Using the event study, we analyzed the effect of the COVID-19 lockdown orders on European and US sustainable indexes.

Our findings show that the European and the US lockdown announcements negatively impacted sustainable indexes; however, the differences between the resilience of sustainable indexes and their conventional peers during the COVID-19 outbreak were not statistically significant. Similarly, our empirical results confirm that screening strategies do not have an impact during severe crises, like the COVID-19 market crash. These results are robust through several model specifications and alternative events.

The absence of a statistically significant difference between an abnormal return of sustainable and traditional indexes during the COVID-19 lockdowns has relevant practical implications. Financial-first investors may alternatively choose sustainable or traditional investments when a bear market occurs because they "may have not to pay the price" for sustainability, as also suggested by Leite and Cortez [37]. Consequently, ceteris paribus, the investment in sustainable assets appears preferable given the opportunity to foster a positive economy.

Thus, our results may support the growth of a sustainable market and a set of products-structured products, ETFs, ETNs, and funds-linked with such sustainable indexes, although some policy issues related to the ESG screening methodologies used by sustainable indexes exist. Indeed, the concerns on ESG screening [78-80] are still ongoing and surely justify the European actions aimed at fostering such processes. Establishing international working groups and supranational authorities with the power to investigate and regulate the ESG scoring of large providers of ESG data as well as of large asset managers appears useful, timely and highly needed to foster a trustworthy market of ESG investments. Similarly, research covering this area of investigation appears useful and timely.

Limitations in our findings can be found in the focus on a specific, although relevant, event: the pandemic lockdowns. Thus, future research may analyze long-term performance spanning the pandemic outbreak period, which has not yet run its course.

Author Contributions: Conceptualization, H.C., G.V. and L.D.P.; methodology, H.C.; formal analysis, H.C., L.D.P.; data curation, H.C., L.D.P. writing-original draft preparation; writing H.C., G.V. review and editing, H.C., G.V.; supervision H.C., G.V. All authors have read and agreed to the published version of the manuscript.

Funding: This research received no external funding.

Institutional Review Board Statement: Not applicable.

Informed Consent Statement: Not applicable.

Data Availability Statement: Not applicable.

Conflicts of Interest: The authors declare no conflict of interest.

\section{References}

1. Sandberg, J.; Juravle, C.; Hedesström, T.M.; Hamilton, I. The heterogeneity of socially responsible investment. J. Bus. Ethics 2009, 87, 519. [CrossRef]

2. Yen, M.F.; Shiu, Y.M.; Wang, C.F. Socially responsible investment returns and news: Evidence from Asia. Corp. Soc. Responsib. Environ. Manag. 2019, 26, 1565-1578. [CrossRef]

3. Nofsinger, J.; Varma, A. Socially responsible funds and market crises. J. Bank. Financ. 2014, 48, 180-193. [CrossRef]

4. Auer, B.R. Do socially responsible investment policies add or destroy European stock portfolio value? J. Bus. Ethics 2016, 135, 381-397. [CrossRef]

5. Yu, E.P.Y.; Guo, C.Q.; Luu, B.V. Environmental, social and governance transparency and firm value. Bus. Strategy Environ. 2018, 27, 987-1004. [CrossRef] 
6. Global Sustainable Investment Alliance. 2018 Global Sustainable Investment Review. 2019. Available online: http:/ /www.gsialliance.org/wp-content/uploads/2019/03/GSIR_Review2018.3.28.pdf (accessed on 5 May 2020).

7. Renneboog, L.; Ter Horst, J.; Zhang, C. Socially responsible investments: Institutional aspects, performance, and investor behavior. J. Bank. Financ. 2008, 32, 1723-1742. [CrossRef]

8. Höchstädter, A.K.; Scheck, B. What's in a name: An analysis of impact investing understandings by academics and practitioners. J. Bus. Ethics 2015, 132, 449-475. [CrossRef]

9. Alijani, S.; Karyotis, C. Coping with impact investing antagonistic objectives: A multistakeholder approach. Res. Int. Bus. Financ. 2019, 47, 10-17. [CrossRef]

10. Lagoarde-Segot, T. Sustainable finance. A critical realist perspective. Res. Int. Bus. Financ. 2019, 47, 1-9. [CrossRef]

11. Rathner, S. The Influence of Primary Study Characteristics on the Performance Differential between Socially Responsible and Conventional Investment Funds: A Meta-Analysis. J. Bus. Ethics 2013, 118, 349-363. [CrossRef]

12. Revelli, C.; Viviani, J.L. Financial performance of socially responsible investing (SRI): What have we learned? A meta-analysis. Bus. Ethics A Eur. Rev. 2015, 24, 158-185. [CrossRef]

13. Freireich, J.; Fulton, K. Investing for Social and Environmental Impact: A Design for Catalyzing an Emerging Industry; Monitor Institute: New York, NY, USA, 2009.

14. Parguel, B.; Benoît-Moreau, F.; Larceneux, F. How Sustainability Ratings Might Deter 'Greenwashing': A Closer Look at Ethical Corporate Communication. J. Bus. Ethics 2011, 102, 15. [CrossRef]

15. Revelli, C. Socially responsible investing (SRI): From mainstream to margin? Res. Int. Bus. Financ. 2017, 39, 711-717. [CrossRef]

16. Bachelet, M.J.; Becchetti, L.; Manfredonia, S. The green bonds premium puzzle: The role of issuer characteristics and third-party verification. Sustainability 2019, 11, 1098. [CrossRef]

17. Yu, E.P.Y.; Van Luu, B.; Chen, C.H. Greenwashing in environmental, social and governance disclosures. Res. Int. Bus. Financ. 2020, 52, 101192. [CrossRef]

18. Endrikat, J. Market reactions to corporate environmental performance related events: A meta-analytic consolidation of the empirical evidence. J. Bus. Ethics 2016, 138, 535-548. [CrossRef]

19. Broadstock, D.C.; Chan, K.; Cheng, L.T.; Wang, X. The role of ESG performance during times of financial crisis: Evidence from COVID-19 in China. Financ. Res. Lett. 2020, 101716. [CrossRef]

20. Folger-Laronde, Z.; Pashang, S.; Feor, L.; ElAlfy, A. ESG ratings and financial performance of exchange-traded funds during the COVID-19 pandemic. J. Sustain. Financ. Investig. 2020, 1-7. [CrossRef]

21. Baker, S.R.; Bloom, N.; Davis, S.J.; Kost, K.; Sammon, M.; Viratyosin, T. The unprecedented stock market reaction to COVID-19. Rev. Asset Pricing Stud. 2020, 10, 742-758. [CrossRef]

22. Coibion, O.; Gorodnichenko, Y.; Weber, M. The Cost of the Covid-19 Crisis: Lockdowns, Macroeconomic Expectations, and Consumer Spending (No. w27141); National Bureau of Economic Research: Cambridge, MA, USA, 2020.

23. Gupta, S.; Montenovo, L.; Nguyen, T.D.; Rojas, F.L.; Schmutte, I.M.; Simon, K.I.; Weinberg, B.A.; Wing, C. Effects of Social Distancing Policy on Labor Market Outcomes (No. w27280); National Bureau of Economic Research: Cambridge, MA, USA, 2020.

24. Gupta, S.; Nguyen, T.D.; Rojas, F.L.; Raman, S.; Lee, B.; Bento, A.; Simon, K.I.; Wing, C. Tracking Public and Private Response to the Covid-19 Epidemic: Evidence from State and Local Government Actions (No. w27027); National Bureau of Economic Research: Cambridge, MA, USA, 2020.

25. Godfrey, P.C. The relationship between corporate philanthropy and shareholder wealth: A risk management perspective. Acad. Manag. Rev. 2005, 30, 777-798. [CrossRef]

26. Godfrey, P.C.; Merrill, C.B.; Hansen, J.M. The relationship between corporate social responsibility and share-holder value: An empirical test of the risk management hypothesis. Strateg. Manag. J. 2009, 30, 425-445. [CrossRef]

27. Wu, J.; Lodorfos, G.; Dean, A.; Gioulmpaxiotis, G. The market performance of socially responsible investment during periods of the economic cycle-Illustrated using the case of FTSE. Manag. Decis. Econ. 2017, 38, 238-251. [CrossRef]

28. Bouslah, K.; Kryzanowski, L.; M'Zali, B. Social performance and firm risk: Impact of the financial crisis. J. Bus. Ethics 2018, 149, 643-669. [CrossRef]

29. Ashraf, B.N. Stock markets' reaction to COVID-19: Cases or fatalities? Res. Int. Bus. Financ. 2020, 101249. [CrossRef]

30. Al-Awadhi, A.M.; Al-Saifi, K.; Al-Awadhi, A.; Alhamadi, S. Death and contagious infectious diseases: Impact of the COVID-19 virus on stock market returns. J. Behav. Exp. Financ. 2020, 100326. [CrossRef] [PubMed]

31. Engelhardt, N.; Krause, M.; Neukirchen, D.; Posch, P. What drives stocks during the corona-crash? News attention vs. rational expectation. Sustainability 2020, 12, 5014. [CrossRef]

32. Lee, H.S. Exploring the Initial Impact of COVID-19 Sentiment on US Stock Market Using Big Data. Sustainability 2020, $12,6648$. [CrossRef]

33. Liu, H.; Manzoor, A.; Wang, C.; Zhang, L.; Manzoor, Z. The COVID-19 outbreak and affected countries stock markets response. Int. J. Environ. Res. Public Health 2020, 17, 2800. [CrossRef] [PubMed]

34. Consolandi, C.; Jaiswal-Dale, A.; Poggiani, E.; Vercelli, A. Global standards and ethical stock indexes: The case of the Dow Jones Sustainability Stoxx Index. J. Bus. Ethics 2009, 87, 185-197. [CrossRef]

35. Cunha, F.A.F.D.S.; de Oliveira, E.M.; Orsato, R.J.; Klotzle, M.C.; Cyrino Oliveira, F.L.; Caiado, R.G.G. Can sustainable investments outperform traditional benchmarks? Evidence from global stock markets. Bus. Strategy Environ. 2020, 29, 682-697. [CrossRef] 
36. Lean, H.H.; Pizzutilo, F. Performances and risk of socially responsible investments across regions during crisis. Int. J. Financ. Econ. 2020. [CrossRef]

37. Leite, P.; Cortez, M.C. Performance of European socially responsible funds during market crises: Evidence from France. Int. Rev. Financ. Anal. 2015, 40, 132-141. [CrossRef]

38. Nakai, M.; Yamaguchi, K.; Takeuchi, K. Can SRI funds better resist global financial crisis? Evidence from Japan. Int. Rev. Financ. Anal. 2016, 48, 12-20. [CrossRef]

39. Silva, F.; Cortez, M.C. The performance of US and European green funds in different market conditions. J. Clean. Prod. 2016, 135, 558-566. [CrossRef]

40. Sustainable Stock Exchange. Report on Progress 2018; SSE Initiative: New York, NY, USA, 2018.

41. Sustainable Stock Exchange. Ten Years on Impact and Progress. Sustainable Stock Exchange 2009-2019; SSE Initiative: New York, NY, USA, 2019.

42. Schröder, M. Is there a difference? The performance characteristics of SRI equity indexes. J. Bus. Financ. Account. 2007, 34, 331-348. [CrossRef]

43. HLEG—High Level Expert Group on Sustainable Finance. Financing a Sustainable European Economy. European Commission, Ed.; 2018. Available online: https:/ / ec.europa.eu/info/sites/info/files/170713-sustainable-finance-report_en.pdf (accessed on 25 April 2019).

44. Chen, X.; Scholtens, B. The urge to act: A comparison of active and passive socially responsible investment funds in the United States. Corp. Soc. Responsib. Environ. Manag. 2018, 25, 1154-1173. [CrossRef]

45. Capelle-Blancard, G.; Monjon, S. Trends in the literature on socially responsible investment: Looking for the keys under the lamppost. Bus. Ethics 2012, 21, 239-250. [CrossRef]

46. Schotland, R.A. Divergent investing for pension funds. Financ. Anal. J. 1980, 36, 29-39. [CrossRef]

47. Clacher, I.; Hagendorff, J. Do announcements about corporate social responsibility create or destroy shareholder wealth? Evidence from the UK. J. Bus. Ethics 2012, 106, 253-266. [CrossRef]

48. Leite, P.; Cortez, M.C. Style and performance of international socially responsible funds in Europe. Res. Int. Bus. Financ. 2014, 30, 248-267. [CrossRef]

49. Hamilton, S.; Jo, H.; Statman, M. Doing well while doing good? The investment performance of socially responsible mutual funds. Financ. Anal. J. 1993, 49, 62-66. [CrossRef]

50. Humphrey, J.E.; Lee, D.D.; Shen, Y. Does it cost to be sustainable? J. Corp. Financ. 2012, 18, 626-639. [CrossRef]

51. Sauer, D.A. The impact of social-responsibility screens on investment performance: Evidence from the Domini 400 Social Index and Domini Equity Mutual Fund. Rev. Financ. Econ. 1997, 6, 137-149. [CrossRef]

52. Collison, D.J.; Cobb, G.; Power, D.M.; Stevenson, L.A. The financial performance of the FTSE4Good indices. Corp. Soc. Responsib. Environ. Manag. 2008, 15, 14-28. [CrossRef]

53. Hoti, S.; McAleer, M.; Pauwels, L.L. Measuring risk in environmental finance. J. Econ. Surv. 2007, 21, 970-998. [CrossRef]

54. Managi, S.; Okimoto, T.; Matsuda, A. Do socially responsible investment indexes outperform conventional indexes? Appl. Financ. Econ. 2012, 22, 1511-1527. [CrossRef]

55. Ur Rehman, R.; Zhang, J.; Uppal, J.; Cullinan, C.; Akram Naseem, M. Are environmental social governance equity indices a better choice for investors? An Asian perspective. Bus. Ethics 2016, 25, 440-459. [CrossRef]

56. Fama, E.F.; French, K.R. Common risk factors in the returns on stocks and bonds. J. Financ. Econ. 1993, 33, 3-56. [CrossRef]

57. Carhart, M.M. On persistence in mutual fund performance. J. Financ. 1997, 52, 57-82. [CrossRef]

58. Becchetti, L.; Ciciretti, R.; Dalò, A.; Herzel, S. Socially responsible and conventional investment funds: Performance comparison and the global financial crisis. Appl. Econ. 2015, 47, 2541-2562. [CrossRef]

59. Bollen, N.P.; Busse, J.A. On the timing ability of mutual fund managers. J. Financ. 2001, 56, 1075-1094. [CrossRef]

60. Matallín-Sáez, J.C.; Soler-Domínguez, A.; de Mingo-López, D.V.; Tortosa-Ausina, E. Does socially responsible mutual fund performance vary over the business cycle? New insights on the effect of idiosyncratic SR features. Bus. Ethics 2019, 28, 71-98. [CrossRef]

61. Ducassy, I. Does corporate social responsibility pay off in times of crisis? An alternate perspective on the relationship between financial and corporate social performance. Corp. Soc. Responsib. Environ. Manag. 2013, 20, 157-167. [CrossRef]

62. Keele, D.M.; DeHart, S. Partners of USEPA climate leaders: An event study on stock performance. Bus. Strategy Environ. 2011, 20, 485-497. [CrossRef]

63. Jiang, Y.; Luo, L. Market reactions to environmental policies: Evidence from China. Corp. Soc. Responsib. Environ. Manag. 2018, 25, 889-903. [CrossRef]

64. Aureli, S.; Gigli, S.; Medei, R.; Supino, E. The value relevance of environmental, social, and governance disclosure: Evidence from Dow Jones Sustainability World Index listed companies. Corp. Soc. Responsib. Environ. Manag. 2020, 27, 43-52. [CrossRef]

65. Corbet, S.; Gurdgiev, C.; Meegan, A. Long-term stock market volatility and the influence of terrorist attacks in Europe. Q. Rev. Econ. Financ. 2018, 68, 118-131. [CrossRef]

66. Goodell, J.W.; Huynh, T.L.D. Did Congress trade ahead? Considering the reaction of US industries to COVID-19. Financ. Res. Lett. 2020, 36, 101578. [CrossRef]

67. MacKinlay, A.C. Event studies in economics and finance. J. Econ. Lit. 1997, 35, 13-39. 
68. Ramiah, V.; Pichelli, J.; Moosa, I. Environmental regulation, the Obama effect and the stock market: Some empirical results. Appl. Econ. 2015, 47, 725-738. [CrossRef]

69. Carboni, M.; Fiordelisi, F.; Ricci, O.; Lopes, F.S.S. Surprised or not surprised? The investors' reaction to the comprehensive assessment preceding the launch of the banking union. J. Bank. Financ. 2017, 74, 122-132. [CrossRef]

70. Boehmer, E.; Masumeci, J.; Poulsen, A.B. Event-study methodology under conditions of event-induced variance. J. Financ. Econ. 1991, 30, 253-272. [CrossRef]

71. Uhde, A.; Farruggio, C.; Michalak, T.C. Wealth effects of credit risk securitization in European banking. J. Bus. Financ. Account. 2012, 39, 193-228. [CrossRef]

72. Loipersberger, F. The effect of supranational banking supervision on the financial sector: Event study evidence from Europe. $J$. Bank. Financ. 2018, 91, 34-48. [CrossRef]

73. Kolari, J.W.; Pynnönen, S. Nonparametric rank tests for event studies. J. Empir. Financ. 2011, 18, 953-971. [CrossRef]

74. Fama, E.F. Foundations of Finance; Basic Books: New York, NY, USA, 1976.

75. Brown, S.; Warner, J. Using Daily Stock Returns: The Case of Event Studies. J. Financ. Econ. 1985, 14, 3-31. [CrossRef]

76. Engle, R.F. Autoregressive Conditional Heteroscedasticity with Estimates of the Variance of United Kingdom Inflation. Econom. J. Econom. Soc. 1982, 987-1007. [CrossRef]

77. Savickas, R. Event-induced volatility and tests for abnormal performance. J. Financ. Res. 2003, 26, 165-178. [CrossRef]

78. Escrig-Olmedo, E.; Fernández-Izquierdo, M.A.; Ferrero-Ferrero, I.; Rivera-Lirio, J.M.; Muñoz-Torres, M.J. Rating the raters: Evaluating how ESG rating agencies integrate sustainability principles. Sustainability 2019, 11, 915. [CrossRef]

79. Muñoz-Torres, M.J.; Fernández-Izquierdo, M.A.; Rivera-Lirio, J.M.; Escrig-Olmedo, E. Can environmental, social, and governance rating agencies favor business models that promote a more sustainable development? Corp. Soc. Responsib. Environ. Manag. 2019, 26, 439-452. [CrossRef]

80. Birindelli, G.; Chiappini, H. Climate change policies: Good news or bad news for firms in the European Union? Corp. Soc. Responsib. Environ. Manag. 2020. [CrossRef] 